\title{
Efficacy of New Fungicides in Management of Alternaria solani in Tomato
}

\author{
Pallabi Pattanaik $^{1 *}$ and Anita Priyadarsini ${ }^{2}$ \\ ${ }^{1}$ Seed Science \& Technology, GIET, Gunpur, India \\ ${ }^{2}$ Plant Pathology, OUAT, Bhubaneswar, India \\ *Corresponding author
}

\section{A B S T R A C T}

\begin{tabular}{|l|}
\hline K e y w o r d s \\
Alternaria solani, \\
early blight, PDI., \\
Azoxystrobin, \\
Tebuconazole, \\
Pyraclostrobin, \\
Hexaconazole \\
\hline Article Info \\
\hline Accepted: \\
15 May 2020 \\
Available Online: \\
10 June 2020
\end{tabular}

\section{Keywords}

Alternaria solani, early blight, PDI.

Azoxystrobin,

Tebuconazole,

Pyraclostrobin

Hexaconazole

\section{Accepted:}

Available Online:

10 June 2020

\section{Introduction}

Tomato (Lycopersicon esculentum Mill.) has become one of the most widely grown vegetables in the world and is regarded as a top priority vegetable. Different fungal diseases like early blight, late blight, Fusarium wilt, leaf spot, anthracnose is found to be very common in tomato.

These fungal diseases are destructive worldwide. Yield reduction may vary from $15-20 \%$ and sometimes $89.5 \%$ depending upon the location, season, weather, growth stage of crop and cultivator. Among all these fungal diseases early blight is one of the deadly diseases of tomato and other solanaceous plants.

In recent year, early blight has assumed serious problematic disease in India. Spraying of broad-spectrum fungicides like Mancozeb and Captan has been recommended for the control of early blight of tomato by several workers (Ramakrishnan et al., 1971 and Stevenson 1977). 
In the present study, it is thought worthwhile to test the efficacy of new combination chemicals like Azoxystrobin (11\%) + Tebuconazole (18.3\%), Trifloxysytrobin $(25 \%)+$ Tebuconazole $(50 \%)$, Hexaconazole $(4 \%)+$ Zineb (68\%), Metiram (55\%) + Pyraclostrobin (5\%) along with single Azoxystrobin and a compound with the proven chemical Carbendazim (25\%)+ Mancozeb $(50 \%)$ combination against early blight disease.

\section{Materials and Methods}

The field experiment was conducted at instructional farm of Odisha University of Agriculture and Technology in the early Rabi season of 2018-19 with the tomato variety Utkal Kumari (BT-10). The tomato seedlings were grown in the plastic trays inside the green house. Seed treatment was done with Thiram @ 1g per kg of seed following dry seed dressing method and sown.

25days old seedlings were transplanted in the main field Recommended cultural practices were uniformly followed to raise the crop successfully. Tomato leaves showing typical early blight symptoms were collected from the field and examined microscopically to confirm the presence of the fungus Alternaria solani.

After first appearance of the symptoms of early blight disease in the leaves, the fungicides were sprayed. The spraying were repeated at fifteen days interval. A total of 4 spraying were done. The observation on severity of the disease on the foliage was recorded by using 0-5 scale and percent disease index (PDI) was calculated.

Percent Disease Index =

$\frac{\text { Sum of individual } \text { ratings }}{\text { No. of leaves examined } \times \text { Max disease scale }} \times 100$

\section{Results and Discussion}

The disease scoring before spray were varied from 0 to 1 and the percent disease index was recorded $2.00 \%$ to $3.33 \%$. After 7 days of $1^{\text {st }}$ foliar spray of chemical, in all the chemical sprayed plots the disease score varied from 0 to 2. But in case of untreated control plot the maximum disease score recorded was 5 .

The percent disease index calculated from the disease score was found to be highest in case of untreated control plot (24.67\%). Azoxystrobin (11\%) + Tebuconazole (18.3\%) was found to be most effective in controlling the disease by recording the lowest PDI as $2.67 \%$ followed by Carbendazim $(25 \%)+$ Mancozeb (50\%) having PDI 5.33\%.

It was also found that there was no disease spread in that plot after the first spray, where the chemical Azoxystrobin (11\%) + Tebuconazole $(18.3 \%)$ was sprayed, as the PDI was $2.67 \%$ before the spray.

At the time of harvest, maximum PDI was recorded in the control plot i.e. $45.33 \%$. The plants treated with Azoxystrobin (11\%) + Tebuconazole (18.3\%) had (PDI-8.00\%) and was found the most effective on early blight followed by the PDI of $12.66 \%, 13.3 \%$ and $14.66 \%$ in the plots sprayed with Carbendazim (25\%) + Mancozeb (50\%), Metiram (55\%) + Pyraclostrobin (5\%) and Hexaconazole $(4 \%)+$ Zineb $(68 \%)$.

There is no significant different in PDI recorded in Carbendazim (25\%) + Mancozeb (50\%), Hexaconazole (4\%) + Zineb (68\%) and Metiram (55\%) + Pyraclostrobin (5\%). Least control of disease was recorded in Azoxystrobin (PDI=21.33\%) treated plots.

Total fruit yield was significantly higher in all the treatments i.e. sprayed with chemicals as compared to control. 
Table.1 Efficacy of new chemicals against early blight disease and fruit yield of tomato under field condition

\begin{tabular}{|c|c|c|c|c|c|c|c|c|}
\hline $\begin{array}{l}\text { Sl. } \\
\text { No. }\end{array}$ & Name of fungicides & $\begin{array}{l}\text { Trade } \\
\text { name }\end{array}$ & $\begin{array}{c}\text { Conc. } \\
(\%)\end{array}$ & $\begin{array}{c}\text { PDI } \\
\text { before } 1^{\text {st }} \\
\text { spray } \\
(\%)\end{array}$ & $\begin{array}{c}\text { PDI at } 7 \\
\text { days after } \\
1^{\text {st }} \text { spray } \\
(\%)\end{array}$ & $\begin{array}{c}\text { PDI at } 7 \\
\text { days after } \\
2^{\text {nd }} \text { spray } \\
(\%)\end{array}$ & $\begin{array}{c}\text { PDI at } \\
\text { harvest } \\
(\%)\end{array}$ & $\begin{array}{l}\text { Fruit } \\
\text { yield } \\
\text { (kg/ha) }\end{array}$ \\
\hline 1 & $\begin{array}{l}\text { T1-Carbendazim } \\
(25 \%)+\text { Mancozeb } \\
(50 \%)\end{array}$ & Sprint & 0.15 & $\begin{array}{c}2.67 \\
(1.61)\end{array}$ & $5.33(2.30)$ & $6.00(2.43)$ & $\begin{array}{c}12.66 \\
(20.66)\end{array}$ & 31676 \\
\hline 2 & $\begin{array}{l}\text { T2-Azoxystrobin } \\
(11 \%)+\text { Tebuconazole } \\
(18.3 \%)\end{array}$ & Custodia & 0.03 & $\begin{array}{c}2.67 \\
(1.61)\end{array}$ & $2.67(1.61)$ & $3.33(1.80)$ & $\begin{array}{c}8.00 \\
(16.35)\end{array}$ & 35080 \\
\hline 3 & $\begin{array}{l}\text { T3-Hexaconazole } \\
(4 \%)+\text { Zineb }(68 \%)\end{array}$ & Avtar & 0.075 & $\begin{array}{l}2.00 \\
(1.41)\end{array}$ & $9.33(3.05)$ & $10.00(3.15)$ & $\begin{array}{c}14.66 \\
(22.45)\end{array}$ & 28149 \\
\hline 4 & $\begin{array}{l}\text { T4-Trifloxysytrobin } \\
(25 \%)+\text { Tebuconazole } \\
(50 \%)\end{array}$ & Nativo & 0.075 & $\begin{array}{c}2.67 \\
(1.61)\end{array}$ & $8.00(2.81)$ & $8.67(2.94)$ & $\begin{array}{c}16.66 \\
(24.04)\end{array}$ & 27626 \\
\hline 5 & $\begin{array}{l}\text { T5-Metiram }(55 \%)+ \\
\text { Pyraclostrobin }(5 \%)\end{array}$ & Clutch & 0.06 & $\begin{array}{c}3.33 \\
(1.80)\end{array}$ & $11.33(3.36)$ & $12.67(3.55)$ & $\begin{array}{l}13.33 \\
(21.40)\end{array}$ & 28104 \\
\hline 6 & T6-Azoxystrobin & Arrivo & 0.025 & $\begin{array}{c}2.67 \\
(1.61)\end{array}$ & $14.67(3.82)$ & $18.67(4.32)$ & $\begin{array}{l}21.33 \\
(27.44)\end{array}$ & 22049 \\
\hline 7 & T7-Untreated & - & - & $\begin{array}{c}2.67 \\
(1.61)\end{array}$ & $24.67(4.92)$ & $28.00(5.29)$ & $\begin{array}{c}45.33 \\
(42.32)\end{array}$ & 16162 \\
\hline & \multicolumn{3}{|c|}{$\mathrm{SE}(\mathrm{m}) \pm$} & NS & 0.144 & 0.147 & 0.86 & 909.99 \\
\hline & \multicolumn{3}{|l|}{$\mathrm{CD}$} & NS & 0.44 & 0.45 & 2.65 & 2803.79 \\
\hline
\end{tabular}

However, the maximum yield (35.08 t/ha) was obtained in plots sprayed with Azoxystrobin (11\%) + Tebuconazole (18.3\%) and least yield (20.72t/ha) was recorded in Azoxystrobin. However, Azoxystrobin had significantly higher fruit yield as compared to untreated control plots (16.16 t/ha).

Among the fungal diseases early blight caused by Alternaria solani is one of the most destructive disease of tomato in tropical and subtropical regions (Raina et al., 2018, Adhikari, 2017 and Thippeswami et al., 2017). The causal organism is seed borne as well as air borne, causing infection in seedling stage and producing disease in plant leaves. The severe disease cause direct loss by infection on fruits resulting fruit rot. To effectively control the early blight disease, chemical management is the only way to reduce the disease severity. From the present investigation it was found that application of strobilurin groups of fungicides (Azoxystobin and Tryfloxystrobin) combined with Tebuconazole, a trizole fungicide had better control on the early blight disease severity.

\section{References}

Bell AA and wheeler MA. 1986. Biosynthesis and functions of fungal melanins, Annual Review of Phytopathology, 24:411-451.

Ellis JB and Martin GB. 1882. Macrosporium solani E\&M., American Naturalist, 16:1003.

Mathur K and Shekhawat KS. 1986. Chemical control of early blight in kharif sown tomato, Indian Journal of Mycology, Plant Pathology, 16:235- 
238.

Raina ZK, Rather RA, Bhat SA, Wani TA and Dorjey K. 2018. Severity of Alternaria Leaf Spot of Brinjal caused by Alternaria alternate in Kashmir, India, International Journal of Current Microbiology Applied Science, 7(5):322-328.

Ramakrishna L, Kamalanathan and Krishnamurthy CS. 1971. Studies on Alternaria leaf spot of tomato, Madras agriculture Journal, 58:275-280.

Sherf AF and MacNab AA. 1986. Vegetable diseases and their control, John Wiley and Sons, New York, 634-640.

Stevenson WR. 1977. Use of Captofol and Chlorothalonil on reduced application method schedules for tomato disease control in India, Plant Disease Report, 61:803-805.

Thippeswamy B, Krishnappa M, Chakravathy $\mathrm{CN}$ and Sathisha AM. 2007. Pathogenicity and management of Anthracnose and Alternaria leaf spot of Chilli, International Journal of Plant Science, 2(1):39-43.

\section{How to cite this article:}

Pallabi Pattanaik and Anita Priyadarsini. 2020. Efficacy of New Fungicides in Management of Alternaria Solani in Tomato. Int.J.Curr.Microbiol.App.Sci. 9(06): 427-430.

doi: https://doi.org/10.20546/ijcmas.2020.906.056 